\title{
EMISSION REDUCTION TECHNOLOGIES FOR MARINE DIESEL ENGINES: A SYSTEM DYNAMICS APPROACH
}

\author{
Murat PAMIK ${ }^{1}$ \\ Mustafa NURAN ${ }^{2}$ \\ A.Güldem CERIT ${ }^{3}$
}

\begin{abstract}
International Maritime Organization (IMO) adopts international marine safety regulations. The regulations incorporated under Annex VI of IMO's International Convention for the Prevention of Pollution from Ships (MARPOL) entered into force in May 2005. These regulations define the limits for sulphur oxides (SOx) and nitrogen oxides (NOx) emissions from ship exhausts.

In this context, emission reduction technologies needed for enviroment protection and satisfy to sustainabletransportation. This study aims to show the effects of emission reduction technologies for marine diesel engines. It includes 'Direct Water Injection', 'Humid Air Motor', 'Exhaust Gas Recirculation', 'Delayed Fuel Injection Time' and 'Selected Catalytic Reduction' The reseach is based on the system dynamics model.
\end{abstract}

engines

Keywords: Emission Reductions, system dynamics, marine diesel

\footnotetext{
${ }^{1}$ Arş.Gör., Dokuz Eylül Üniversitesi, Denizcilik Fakültesi, murat.pamik@deu.edu.tr

${ }^{2}$ Yrd.Doç.Dr., Dokuz Eylül Üniversitesi, Denizcilik Fakültesi, mustafa.nuran@deu.edu.tr

${ }^{3}$ Prof.Dr., Dokuz Eylül Üniversitesi, Denizcilik Fakültesi, gcerit@deu.edu.tr
} 


\section{GEMI DIZEL MAKINNELERI İÇIN SALIM İNDIRGEME TEKNOLOJILLERI: SİSTEM DİAMIKLERİ YAKLAŞIMI}

\section{ÖZET}

Uluslararası Denizcilik Örgütü (IMO), uluslararası denizcilik emniyet kurallarını geliştiren bir örgüttür. IMO'nun gemi kaynakl hava kirliliğini önlemeye yönelik MARPOL ek VI kuralları Mayls 2005'den itibaren yürürlüğe girmiştir. Bu regülasyonlar gemi eksozundaki sulfur oksit ve azot oksit salımlarının limitlerini belirlemektedir.

Bu çerçevede, çevreyi korumak ve daha sürdürülebilir bir taşımacılık sağlamak için gemi dizel makinelerine ilişkin NOx ve SOx salımlarının azaltılmasına yönelik teknolojilere ihtiyaç duyulmaktadır. Bu çalışma çeşitli teknolojilerin salımlar üzerindeki etkilerini sistem dinamikleri yaklaşımı ile incelemeyi amaçlamaktadır.

Anahtar Kelimeler: Salım indirgeme, sistem dinamikleri, gemi dizel makineleri

\section{INTRODUCTION}

NOx and SOx in the air can damage the leaves of plants, decrease their ability to produce food and decrease their growth. NOx and SOx when deposited on land and in estuaries, lakes and streams, can acidify and over fertilize sensitive ecosystems resulting in a range of harmful indirect effects on plants, soils, water quality, fish and wildlife (EPA, 2011).

Following an extensive evaluation of health evidence from epidemiologic and laboratory studies, the U.S. EPA has concluded that there is sufficient to infer a likely causal relationship between respiratory effects and short-term NO2 exposure. There is also strong evidence provided by studies that there is a causal relationship between respiratory health effects and short-term exposure to $\mathrm{SO} 2$, in some cases, local nervous system reflexes also may be involved. Asthmatics are more sensitive to the effects of SO2 (EPA, 2010).

If a hydrocarbon-based fuel of composition is reacted with air, its complete combustion would yield carbon dioxide, water, oxygen (if lean mixture) and nitrogen. The vast majority of the diluent in air is nitrogen, it is perfectly reasonable to consider air as a mixture of $20.9 \%$ (mole basis) $\mathrm{O}_{2}$ and $79.1 \%$ (mole basis) $\mathrm{N}_{2}$. Thus for every mole of oxygen required for combustion, 3.78 mole of nitrogen must be introduced as 
well. The stoichiometric relation for complete oxidation of a hydrocarbon fuel, $\mathrm{C}_{\mathrm{n}} \mathrm{H}_{\mathrm{m}}$, becomes (Flagan and Seinfeld 2012).

$$
\mathrm{C}_{n} \mathrm{H}_{m}+\left(n+\frac{m}{4}\right)\left(\mathrm{O}_{2}+3.78 \mathrm{~N}_{2}\right) \longrightarrow n \mathrm{CO}_{2}+\frac{m}{2} \mathrm{H}_{2} \mathrm{O}+3.78\left(n+\frac{m}{4}\right) \mathrm{N}_{2}
$$

Thus for every mole of fuel burned, 4.78 mole of combustion products are generated (Flagan and Seinfeld, 2012).

The marine transport sector contributes significantly to air pollution, particularly in coastal areas. Annually, ocean-going ships are estimated to emit 1.2-1.6 million metric tons ( $\mathrm{Tg}$ ) of particulate matter (PM) with aerodynamic diameters of $10 \mu \mathrm{m}$ or less (PM10), 4.7-6.5 Tg of sulfur oxides (SOx as S), and 5-6.9 Tg of nitrogen oxides (NOx as N) (Corbett, 2007: 8512-8518).

Ship emissions represent more than 14 percent of nitrogen emissions from global fuel combustion sources and more than 16 percent of sulfur emissions from world petroleum use. (Corbett, et al., 2007: 8512-8518). Dalsøren et al.(2009) found ship emissions is a dominant contributor over much of the world oceans to surface concentrations of $\mathrm{NO} 2$ and SO2. The contribution is also large over some coastal zones. For surface ozone the contribution is high over the oceans but clearly also of importance over Western North America (contribution 15-25\%) and Western Europe (5-15\%) (Dalsoren et al., 2009: 2171-2194).

Marine vessels use diesel engines which burn diesel oil or mostly heavy fuel oil. All marine fuel used today is created from the same basic distillation process that creates other liquid hydrocarbons such as motor gasoline, heating oil and kerosene. Distillate marine fuels are comparable to other forms of distillate hydrocarbon liquids, such as nonroad diesel fuel or No. 2 fuel oil, in that they have similar chemical properties and specification limits. Residual marine fuels, also called Intermediate Fuel Oils (IFO) or Heavy Fuel Oils (HFO), are composed of heavy, residuum hydrocarbons which are created as a by-product during petroleum refining, and can contain various contaminants such as heavy metals, water, and high sulfur levels (EPA, 2009).

MARPOL 73/78 Annex VI Regulations for the prevention of Air Pollution from ships entered into force on 19 May 2005, the code covers the following (DNV, 2005): 
Regulation 12 - Emissions from Ozone depleting substances from refrigerating plants and fire fighting equipment. engines

Regulation 13 - Nitrogen Oxide (NOx) emissions from diesel

Regulation 14 - Sulphur Oxide (SOx) emissions from ships

Regulation 15 - Volatile Organic compounds emissions from cargo oil tanks of oil tankers

Regulation 16 - Emissions from shipboard incinerators.

Regulation 18 - Fuel Oil quality

With respect to air pollution, the modest international regulation of shipping so far contrasts with the efforts made in relation to land-based sources. As a result of this, and of the steadily increasing transport and cargo volumes transported by sea, shipping has become themain source of man-made emissions of sulphuroxides ( $\mathrm{SOx})$. It is estimated that $\mathrm{SOx}$ emissions from ships in the EU will amount to 75 percent of the total land-based emissions by 2010 and that they will be approximately equal by 2015. MARPOL Annex VI includes standards on maximum sulphur content in marine fuel, but those standards are so high that they almost lose their practical significance, apart from in so-called SOx Emission Control Areas (SECAs) (EMSA, 2008).

SOx emission limits from ships are shown in Table 1;

Table 1. MARPOL Annex VI Sulphur Limits

\begin{tabular}{|c|c|c|c|c|}
\hline \multirow{2}{*}{} & \multicolumn{2}{|c|}{ GLOBAL } & \multicolumn{2}{c|}{ Emission Control Area(ECA) } \\
\hline \multirow{3}{*}{ Fuel Sulphur } & 2004 & $45,000 \mathrm{ppm}$ & 2005 & $15,000 \mathrm{ppm}$ \\
\cline { 2 - 5 } & & & & \\
\cline { 2 - 5 } & 2012 & $35,000 \mathrm{ppm}$ & 2010 & $10,000 \mathrm{ppm}$ \\
\cline { 2 - 5 } & 2020 & $5,000 \mathrm{ppm}$ & 2015 & $1,000 \mathrm{ppm}$ \\
\hline
\end{tabular}

Source: EPA, 2009

The same applies to the regulation of nitrogenoxides (NOx), where the emissions from shipping are expected to equal the total of landbased emissions by 2020. In 2008, MARPOL was significantly revised to change these trends and the new rules on SOx and NOx emissions will be considerably strengthened over time. However, these changes are longterm and will only bring tangible benefits to air quality after a number of years. Regulation on carbondioxide $(\mathrm{CO} 2)$ and other greenhousegases 
from shipping is entirely lacking, despite their contribution being some two to five percent of the global emission total (EMSA, 2008).

Regulation 13 applies to each marine diesel engine with a poweroutput of more than $130 \mathrm{kw}$ installed on a ship (IMO, 2008). Figure 1. show that this regulation according to engine speed.

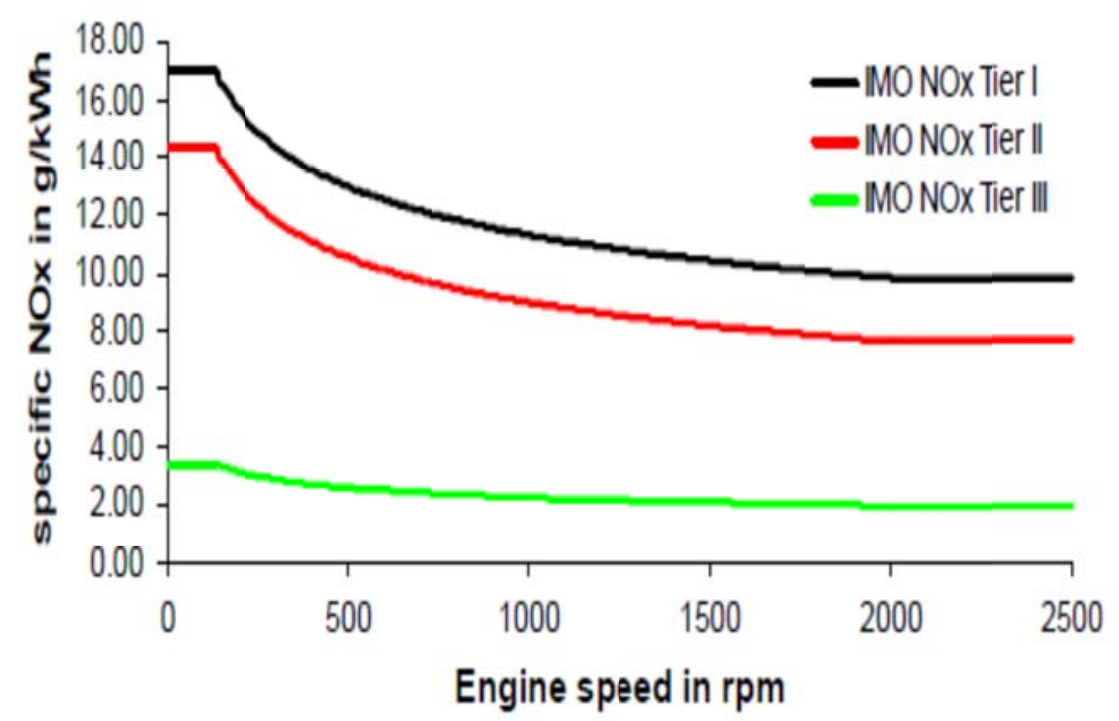

Figure1. Specific NOx amount \& Engine RPM Source: IMO, 2008

In principle, there are four fundamental categories of options for reducing emissions from shipping: a) Improving energy efficiency, b) Using renewable energy sources, c) Using fuels with less total fuel-cycle emissions such as biofuels and natural gas, d) Using emission reduction technologies - i.e. achieving reduction of emissions through chemical conversion, capture and storage, and other options (IMO, 2009).

The decision to choose the most convenient IMO Tier 3 strategy belongs to the ship-owners. Depending on the type of ship, the trade route and the strategies of the ship operators, the principle-based advantages and disadvantages of the different strategies may evaluated differently (Herdzik, 2011:161-167).

Emissions of NOx from diesel engines can be reduced by a number of measures, including (IMO, 2009) 
1. fuel modification, e.g., water emulsion;

2. modification of the charge air, e.g., humidification and exhaust gas recirculation (EGR);

3. modification of the combustion process, e.g., miller timing;

4. treatment of the exhaust gas, e.g., selective catalytic reduction (SCR).

\section{EMISSION REDUCTION TECHNOLOGIES}

\subsection{Selective Catalytic Reduction (SCR)}

The installation of SCR catalysts on board ships has been promoted by the introduction of emission-depending port dues in Sweden and the NOx tax in Norway. Operation even below the limits set for IMO 3 can be achieved by the use of SCR catalysts. (Buchholz, 2010: 76)

The SCR process chemically reduces the NOx molecule in to molecular nitrogen and water vapour. A nitrogen based reagent such as amonia or urea is injected into the ductwork, downstream of the combustion unit. The wastegas with the mixes reagent and enters a reactor module containing catalyst. The hot fluegas and reagent diffuse through the catalyst. The reagent reacts selectively with the NOx within a specific temperature range and in the presence of the catalist and oxygen (EPA, 2002).

Catalysts configurations are generally ceramic honey comp and pleated metal plate (monolith) designs. The catalyst composition, type and physical properties affect performance, reliability, catalyst quantity required and cost. The SCR system supplier and catalyst supplier generally guarantee the catalyst life and performance. Newer catalyst designs increase catalyst activity, surface area per unit volume and the temperature range for the reduction reaction (EPA, 2002).

SCR is capable of NOx reductions efficiencies in the range of $70 \%-95 \%$. Higher reductions are possible but generally are not cost effective (EPA, 2002). Figure 2. shows layout principle of a SCR based IMO tier III strategy. 


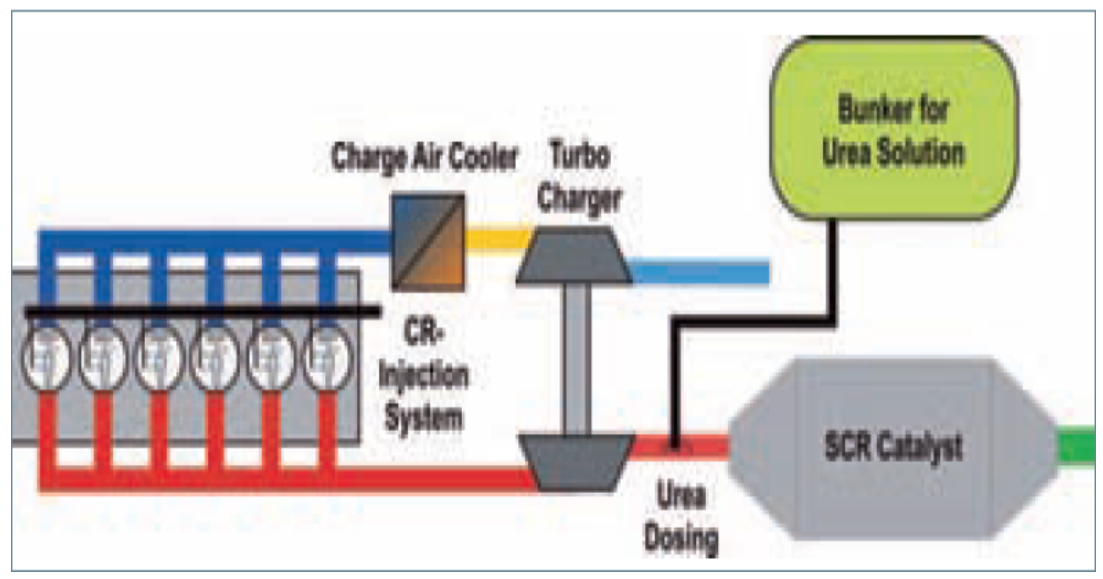

Figure 2. SCR System Description

Source: Buchholz, 2010: 77

\subsection{Direct Water Injection (DWI)}

The engine with direct water injection is equipped with a combined injection valve and nozzle that allows injection of water and fuel oil into the cylinder. This means that neither of the modes (water on /off) will affect the operation of the engine (Wartsila, 2012).

Water is fed to the cylinder head at high pressure, 210 bar. High water pressure is generated in a high-pressure water pump module. The pumps and filters are built into modules to enable easy, and require a minimum of space. A flow fuse is installed on the cylinder head side. The flow fuse acts as a safety device, shutting off the water flow into the cylinder if the water needle gets stuck. Injection timing and duration is electronically controlled by the control unit, which gets its input from the engine output. NOX reduction of $50-60 \%$ can be reached without adversely affecting power output. DWI system can be installed also as aretrofit (Wartsila, 2012).

Bedford \& Rutland (2000) studied the effects of in-cylinder water injection on a direct injection (DI) Diesel engine using a computational fluid dynamics (CFD) program and found vaporization of liquid water as well as a local increase in specific heat of the gas around the flame resulted in lower Nitrogen Oxide emissions. NOx decreased at all loads (Bedford, 2000). 
Miyamoto et al. (1995) investigated the effect of direct water injection into the combustion chamber on NOx reduction in an IDI diesel engine reduced NOx emission significantly over a wide output range without sacrifice of BSFC. Figure 3. shows Wartsila Direct Water Injection System's describtion.

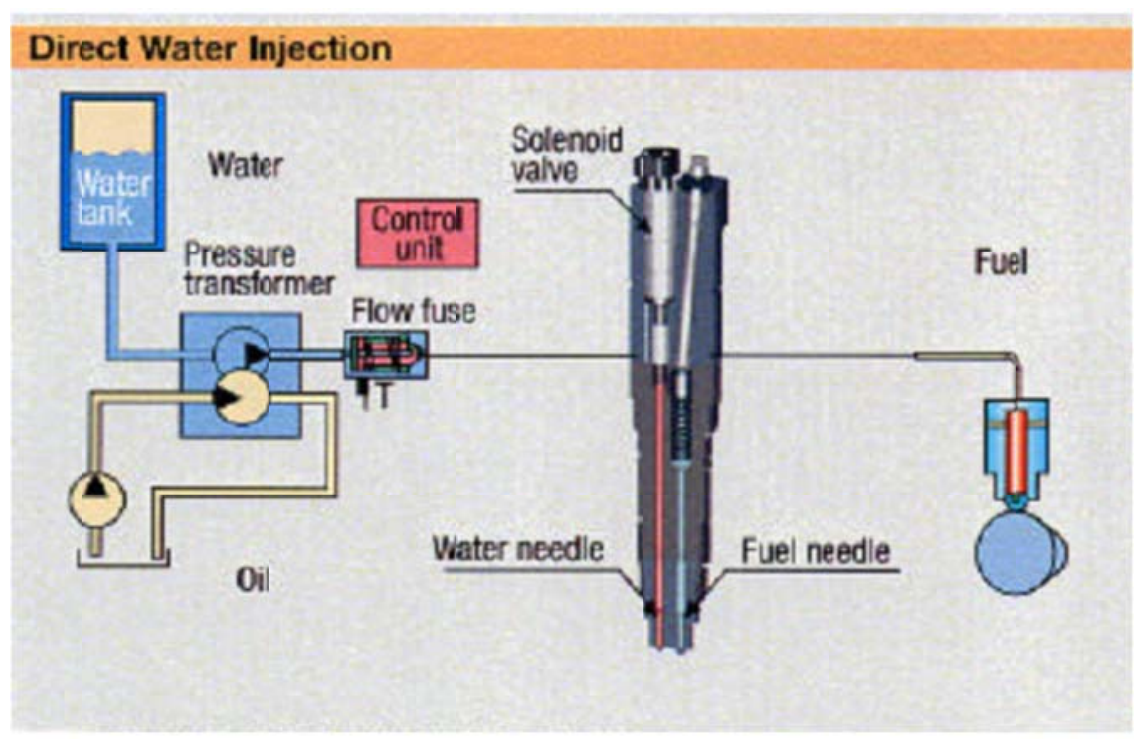

Figure3. DWI System Description

Source: Wartsila, 2012

\subsection{Delayed Fuel Injection Time}

Ignition delay was defined as the time between the start of fuel injection and the start of combustion. The start of injection is usually taken as the time when the injector needle lifts off its seat. Because a needle lift detector was not available, the start of injection was defined to be the Point when the injection line pressure reached 207 bar, the nozzleopening-pressure for the injector. The start of combustion was defined in terms of the change in slope of the heat-release rate that occurs at ignition.Retarded injection timing significantly reduced NOx emissions (Monyem, et al. 2001: 35-42). 


\subsection{Exhaust Gas Recirculation (EGR)}

An effective way for reducing nitrous oxide (NOx) emissions may be accomplished by changing the engine combustion process through the recycling of exhausted gases. This process is accomplished by adding combustion products to the fresh fuel-air mixture during the intake process. This technology is known as Exhaust Gas Recirculation (EGR) (Vianna et al., 2005: 217-222).

Exhaust Gas Recirculation is a method to significantly reduceNOx emissions from marine engines. It is proven to be able to meet the Tier III NOx requirements, which will apply to all new ships entering a NOx Emission Control Area (ECA) from 2016. The illustration in Figure shows an EGR system from MAN Diesel. Part of the exhaust gas is diverted from the exhaust gas receiver through a wet scrubber which cleans the gas and reduces the temperature of the exhaust gas. The gas flows through a cooler and water mist catcher and finally through the EGR blower which lifts the pressure to the scavenge air pressure. A water handling system supplies the scrubber with recirculating fresh water with the addition of $\mathrm{NaOH}$ to neutralize the effect of sulphur in the fuel (Kristensen, 2012).

The effect of this system will be that a minor part of the oxygen in the scavenge air is replaced by $\mathrm{CO} 2$ from the combustion. The heat capacity of the scavengeair will be slightly increased and the temperature peaks of the combustion will be reduced. Accordingly the amount of NOx generated in the combustion chamber is reduced but it is also followed by a minor fuel penalty. The NOx reduction value is dependent on the ratio of recirculating gas (Kristensen, 2012).

It is well known that EGR, besides significantly reducing the NOx emissions, results in an increased SFOC, known as the SFOC penalty. It is experienced that a $10 \%$ increase of EGR results in a $20 \%$ NOx reduction followed by a SFOC penalty of $0.5 \mathrm{~g} / \mathrm{kWh}$ (Kristensen, 2012). Figure 4. shows basic principles of MAN EGR system. 


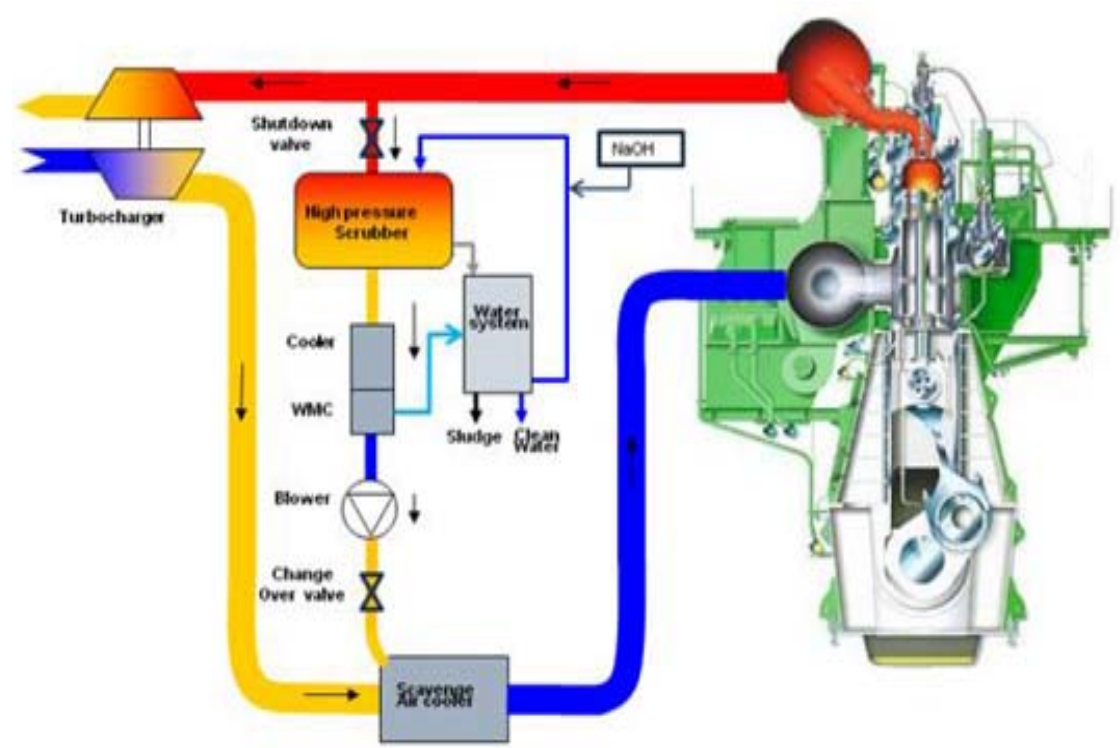

Figure 4. Principles of an EGR System

Source: Man Diesel \& Turbo, 2009

\subsection{Humid Air Motor}

A widely acclaimed technology for reducing NOx pollution from diesel engines is the "Humid Air Motor" (HAM). This technology is able to reduce NOx formation by up to $65 \%$. In the HAM system the turbocharged combustion air is saturated with water vapour produced aboard the ship using sea water and engine heat. This lowers the temperature peaks in the combustion chamber, which are normally the main reason for NOx formation. HAM is characterised by extremely low operating costs due to sea water usage, decreased lube oil consumption, very low maintenance costs and a very high availability factor (MAN $\mathrm{B} \& \mathrm{~W}, 2011)$.

A number of approaches for intake air humidification have been attempted. While there are some differences in the approaches, the most successful intake air humidification systems take significant steps to ensure that only water vapour enters the cylinder and that liquid water does not carry over into the cylinder and cause cylinder liner corrosion problems. In order to get high NOx reductions, this often means that the humidity of the air is near saturation as it enters the engine and that the intake manifold air temperature is as high as the engine can tolerate (Prior et al., 2005: 20). 


\section{METHODOLOGY}

System dynamics is a powerful methodology and computer simulation modeling technique for framing, understanding, and discussing complex issues and problems. Originally developed in the 1950s to help corporate managers improve their understanding of industrial processes (The System Dynamics Society, 2001).

System dynamics is fundamentally interdisciplinary. Because we are concerned with the behavior of complex systems, system dynamics is grounded in the theory of nonlinear dynamics and feed back control developed in mathematics, physics, and engineering. Because we apply these tools to the behavior of human as well as physical and technical systems, system dynamics draws on cognitive and social psychology, economics, and other social sciences. Because we build system dynamics models to solve important real world problems, we must learn how to work effectively with groups of busy policy makers and how to catalyze sustained change in organizations (Sterman, 2001).

System Dynamics can be applied to any dynamic system, with any time and spatial scale. In the World of business and public policy system dynamic has been applied to industries from aircraft to zinc and issues from aids to welfare reform (Sterman, 2000).

System dynamics models are used in analyzing the structure and the behavior of the system as well as for designing efficient policies of managing the system. System dynamics is a powerful tool that enhances learning about company, market and competitors; portrays the cognitive limitations on the information gathering and processing power of human mind; facilitates the practice of considering opinions; and supports building of "What if" scenarios. System dynamics models can help in understanding structure and behavior of the system with nonlinear links and feedback (Pejic et al., 2007).

Causal loop diagrams (CLDs) are an important tool for representing the feedback structure of systems. A causal diagram consists of variables connected by arrows denoting the causal influences among the variables. The important feedback loops are also identified in the diagram (Sterman, 2000). 


\section{(4) 0 ( A B Loop Identifier:Positive (Reinforcing) Loop

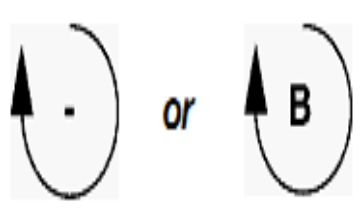 \\ Loop Identifier:'Negative (Balancing) Loop}

Figure 5. Loop Identifiers

Source: Sterman, 2000

A positive link means that if the cause increases, the effect increases above what it would otherwise have been, and if the cause decreases, the effect decreases below what it would otherwise have been. A negative link means that if the cause increases, the effect decreases below what it would otherwise have been, and if the cause decreases, the effect increases above what it would otherwise have been. Note the phrase above what it otherwise would have been in the definition of link polarity. An increase in a cause variable does not necessarily mean the effect will actually increase (Sterman, 2000).

System dynamics is a methodology for studying and managing complex systems which change over time. The method uses computer modeling to focus our attention on the information feedback loops that give rise to the dynamic behavior. Computer simulation is particularly useful when it helps us understand the impact of time delays and nonlinearities in the system. A variety of modeling methods can aid the manager of complex systems. System dynamics has been used extensively in the study of environmental and energy systems (Ford, 2000).

VENSIM is simulation software for improving the performance of real systems. VENSIM is used for developing, analyzing, and packaging dynamic feedback models. The approach we now describe includes several important extensions to the system dynamics toolset (Ventana System, Inc. 2014): 
- Entity type definitions, providing objects or modules

- Attributes used to identify and categorize individual entities

- Collections of entities automatically generated and tracked by attribute

- Aggregation and allocation functions that make one-to-many or many-to-many mappings among collections and individual entities

- References, or special attributes used to connect entities of the same or different types

- Actions, providing for discrete events like the dynamic creation and deletion of entities.

The model of this study have been developed by system dynamics approach and using Vensim Simulation Software. Model aims to show all emission reduction technologies explained above together to be able to understend the situation comperatively.

Table 2. shows the effects of emission reduction technologies.

Table 2. Reduction Effect

\begin{tabular}{|c|c|c|c|c|c|}
\hline $\begin{array}{c}\text { NOx } \\
\text { Reduction } \\
\text { Technologies }\end{array}$ & $\begin{array}{c}\text { Delayed } \\
\text { Fuel } \\
\text { Injection } \\
\text { Time }\end{array}$ & $\begin{array}{c}\text { Exhaust Gas } \\
\text { Recirculation } \\
\text { (EGR) }\end{array}$ & $\begin{array}{c}\text { Humid } \\
\text { Air } \\
\text { Motor } \\
\text { (HAM) }\end{array}$ & $\begin{array}{c}\text { Direct } \\
\text { Water } \\
\text { Injection } \\
\text { (DWI) }\end{array}$ & $\begin{array}{c}\text { Selective } \\
\text { Catalytic } \\
\text { Reduction } \\
\text { (SCR) }\end{array}$ \\
\hline $\begin{array}{c}\text { Reduction } \\
\text { Effect }\end{array}$ & $\% 2-3$ & $\% 50$ & $\begin{array}{c}\% 50- \\
80\end{array}$ & $\% 20-50$ & $\% 75-95$ \\
\hline
\end{tabular}

Source: Prior, et al., 2005

In figure 6, there is an 'Initial NOx Emission Amount' which represents to last limit of NOx Emission amount according to MARPOL Annex VI Tier I for slow speed diesel engines. This value simulated with some emission reduction technologies with use of vensim to reduce until it will be appropriate according to MARPOL Annex VI Tier III for slow speed diesel engines. 


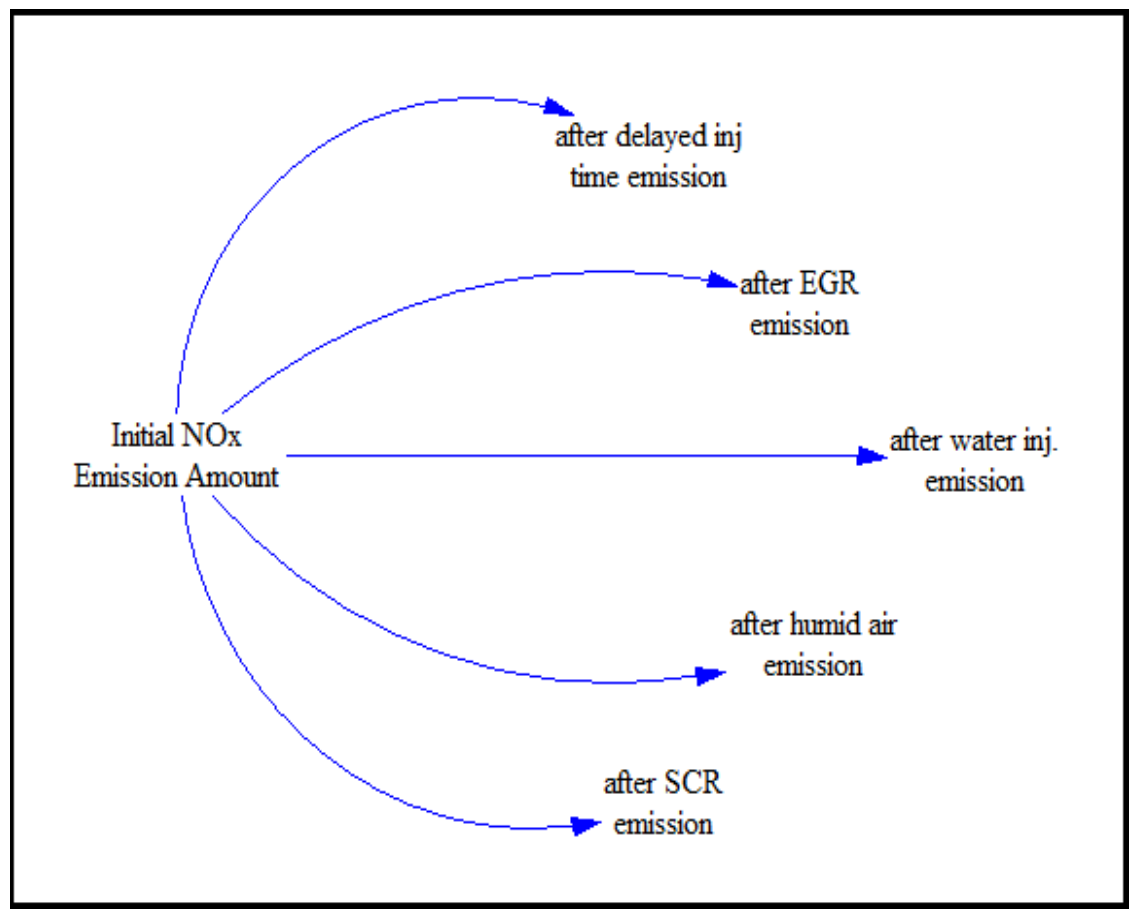

Figure 6. Effect of Emission Reduction Technologies Source: Authors

Initial NOx Emission value is $17 \mathrm{~g} / \mathrm{kwh}$ according to MARPOL Annex VI Tier I

-Firstly, it has been simulated with 'Delayed Fuel Injection time' technology. This technology affected NOx emission amount about 3\% and the result of emission is $16.49 \mathrm{~g} / \mathrm{kwh}$.

-When it has been simulated with 'Direct Water Injection' technology, we have seen that, this technology affected NOx Emission amount about $40 \%$ and the result of emission is $10.2 \mathrm{~g} / \mathrm{kwh}$.

- It has been simulated with 'Selected Catalytic Reduction' technology. This technology affected NOx emission amount about $90 \%$ and the result of emission is $1.7 \mathrm{~g} / \mathrm{kwh}$.

- It has been simulated with 'Humid Air Motor' technology. This technology affected NOx emission amount about $75 \%$ and the result of emission is $4.25 \mathrm{~g} / \mathrm{kwh}$.

- It has been simulated with 'Exhaust Gas Recirculation'. This technology effected NOx emission amount about $50 \%$ and the result of emission is $8.5 \mathrm{~g} / \mathrm{kwh}$. 
-It is clearly seen that all these technologies has significant effect on reducing NOx emissions. Also most of these technologies not enough to conform to reduce emissions from maximum limit in tier I to minimum limit to tier III. However, some of these technology can be used joint with each other.

-It has been simulated with 'Humid Air Motor' and 'Exhaust Gas Recirculation'. These two technologies affected NOx emission amount about $87.5 \%$ and the result of emission is $2.12 \mathrm{~g} / \mathrm{kwh}$. Of course it is just a theoretical value and both system can affect each other negatively.

On the other hand; these technologies have some costs which are initial and operational costs. It has needed to be paid for set up and fuel oil consumption would increase correspondingly to this. Managers and engineers have to account this factor before set up. There is a trade-off situation to reduce NOx Emission amount and providing to low fuel oil consumption. Figure 7. shows this trade-off with use system dynamics' causal loop diagrams.

Figure 7 explains the complicated trade-off between cost and emission with causal loop diagrams. The first loop is about using 'Direct Water Injection System'. This system effects to decrease combustion temperature so it also affects to decrease NOx emissions. However, in order to install cost, this system effects negatively (-) to efficiency of lubrication oil, low efficiency of lubrication oil effects negatively (-) to cavitation, it means increase of cavitation and this cause rises $(+)$ repair costs.

The other loop is concerned with 'Delayed Fuel Injection Time'. This system affects to decrease combustion preassure and also it effects to decrease combustion temperature, then it again decreases to NOx emissions. However, in order to install cost, this system increases $(+)$ the fuel consumption.

Using 'Humid Air Motor' constitutes another causal loop. This system reduces scavange air and also combustion air temperature so it affects to decrease NOx emission amount. However, this system also has installation and operational costs.

'Selected Catalytic Reduction' and 'Exhaust Gas Recirculation' systems loops give us the similer results. These systems are highly effective to reduces NOx emissions, but especially 'Selected Catalytic Reduction' system has a significant installation cost 


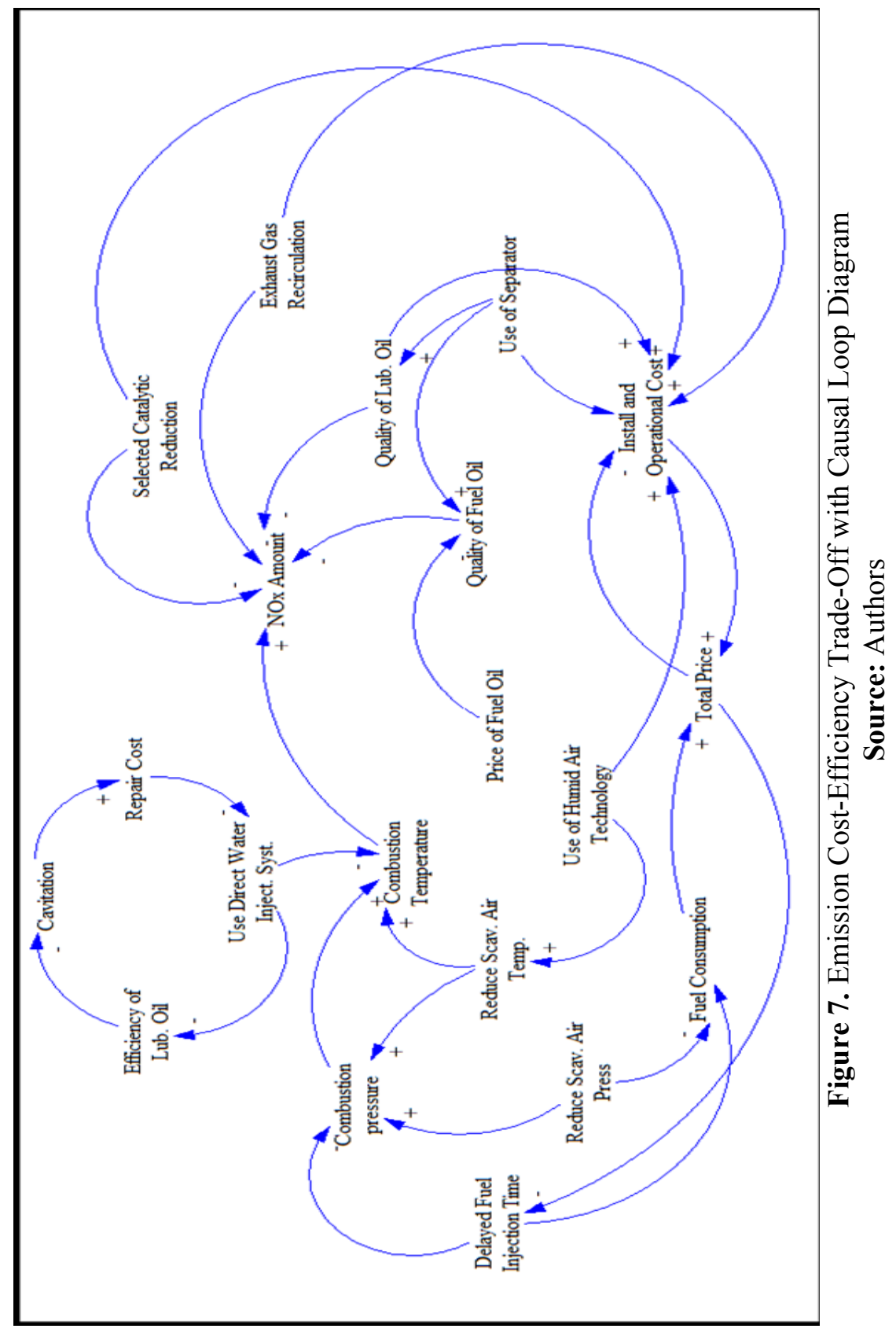




\section{CONCLUSION}

This study discussed the relevant technologies in the realization of emission limits designated by IMO to prevent air pollution and system dynamics simulations have been introduced as an alternative method to analyze the problems.

It could be concluded that since it is mandatory to use emission reduction technologies in order to comply with the new regulations, further studies should be realized based on more effective and economical approaches. System dynamics simulations provide an alternative way of approaching the problem. Ths study can be repeated as an experimental and quantitative research with the existence of numerical data.

\section{REFERENCES}

BEDFORD, F., RUTLAND, C., DITTRICH, P., RAAB, A., WIBERLEIT, F. (2000) Effects of Direct Water Injection on DI Diesel Engine Combustion, SAE Technical Paper, No. 2000-01-2938.

BUCHHOLZ, B., HARNDORF, H., FINK, C. (2010) IMO Tier III Strategies \& Challenges, Ship \& Offshore, No:4.

CORBETT, J., WINEBRAKE, J., GREEN, E., KASIBHATLA, P., EYRING, V., LAUER, A. (2007) Mortality from Ship Emissions: A Global Assessment, Environmental Science \& Technology, Vol.41, No.24, pp. 8512-8518.

DALSOREN, S. B., EIDE, M.S., ENDRESEN, O., MJELDE, A., GRAVIR, G., ISAKSEN, I.S.A. (2009). Update on Emissions and Environmental Impacts from the International Fleet of Ships, The Contribution from Major Ship Types and Ports, Atmospheric Chemistry and Physics, Vol.9, No.6, pp.2171-2194

DNV (2005) Marpol 73/78 Annex VI Regulations for the Prevention of Air Pollution from Ships

http://www.dnv.com/binaries/marpol\%20brochure_tcm4-383718.pdf, Erişim Tarihi: 18.10 .2014

EMSA (2008) Preventing Pollution From Ships, Erişim Tarihi: 23.10.2014 
EPA (2011) Fact Sheet Proposed Revisions to the Secondary National Ambient Air Quality Standarts For Oxides of Nitrogen and Sulfur, http:/www.epa.gov/airquality/nitrogenoxides/pdfs/NOxSOxProposalFact Sheetfinal.pdf, Erişim Tarihi: 20.10.2014

EPA (2010) Proposal to Designate an Emission Control Area for Nitrogen Oxides, Sulfur Oxides and Particulate Matter, http://www.epa.gov/otaq/regs/nonroad/marine/ci/420r10013.pdf, Erişim Tarihi: 10.09 .2014

EPA (2009) Draft Regulatory Impact Analysis: Control of Emissions of Air Pollution from Category 3 Marine Diesel Engines. http://www.epa.gov/nonroad/marine/ci/420d09002.pdf, Erişim Tarihi: 10.09.2014

EPA (2002) Air Pollution Control Technology Fact Sheet, http://www.epa.gov/ttncatc1/dir1/fscr.pdf, Erişim Tarihi: 08.09.2014.

FLAGAN, R. C. ve SEINFELD, J.H. (2012) Fundamentals of Air Pollution Engineering, Courier Dover Publications.

FORD, A. (2000) Modeling the Environment: An Introduction to System Dynamics Modeling of Environmental Systems, International Journal of Sustainability in Higher Education, Vol.1, No.1.

HERDZIK, J. (2011) Emissions from Marine Engines versus IMO Certification and Requirements of Tier 3, Journal of KONES, Vol.18, pp. 161-167.

IMO (2008) Prevention of Air Pollution from Ships Revised MARPOL Annex VI and NOx Technical Code 2008,http://www.glgroup.com/pdf/RevisedMARPOL_AnnexVI.pdf, Erişim Tarihi: 03.09.2014

IMO (2009) Second IMO GHG Study 2009, http://www.imo.org/blast/blastDataHelper.asp?data_id=2779, Erişim Tarihi: 12.10 .2014

KRISTENSEN, H. O. (2012) Energy Demand and Exhaust Gas Emissions of Marine Engines, Clean Shipping Currents, Vol.1, No.6. 
MAN B\&W (2011) Humid Air Motor Technology for Green Profits, http://mandieselturbo.com/files/news/filesof15316/HAM_PS_Brochure_ May2011.pdf, Erişim Tarihi: 12.10.2104

MAN DIESEL \& TURBO (2009) Exhaust Gas Emission Control Today and Tomorrow,

http://www.mandieselturbo.com/files/news/filesof9187/5510-0060-

01ppr_low.pdf, Erişim Tarihi: 12.10.2014

MIYAMOTO, N., OGAWA, H., WANG, J., and OHASHI, H. (1995) Significant NOx Reductions with Direct Water Injection into the SubChamber of an IDI Diesel Engine, SAE Technical Paper, 950609.

MONYEM, A., VAN GERPEN, J. H., CANAKCL, M. (2001) The Effect of Timing and Oxidation on Emissions from Biodiesel-fueled Engines, Carbon,Vol. 44, No.1, pp.35-42.

PEJIC-BACH, M., and CERIC, V. (2007) Developing System Dynamics Models with Step-by-step Approach, Journal of Information and Organizational Sciences, Vol.31. No.1 pp. 171-185.

PRIOR, A., JAASKELAINEN, H. and WALSH, J. (2005). Nox Emission Study: an Investigation of Water-Based Emission Control Technologies. No. TP 14497E.p: 20

STERMAN, J.D. (2001) System Dynamics Modeling, California Management Review, Vol.43, No.4,pp. 8-25.

STERMAN, J.D. (2000) Business Dynamics: Systems Thinking and Modeling for a Complex World, Vol. 19. Boston: Irwin/McGraw-Hill, 4142.

THE SYSTEM DYNAMICS SOCIETY (2001) The System Dynamics Review, http:/www.systemdynamics.org/DL-IntroSysDyn/start.htm, Erişim Tarihi: 23.09.2014

VIANNA, J.N de S., REIS, A. do V., OLIVEIRA, A.B. de S., FRAGA, A.G., SOUSA, M.T. (2005). Reduction of Pollutants Emissions on SI Engines: Accomplishments with Efficiency Increase, Journal of the Brazilian Society of Mechanical Sciences and Engineering, Vol. 27, No.3 pp.217-222. 
VENTANA Systems, Inc. (2014) Entity-Based System Dynamics, http://vensim.com/wp-content/uploads/2014/08/Entity-Based-SystemDynamics-v2.pdf, Erişim Tarihi: 25.09.2014

WARTSILA (2012) Technology Review, http://www.dieselduck.info/machine/01\%20prime\%20movers/rhapsody\% 20de1/Wartsila\%20W46.pdf, $\quad$ Erişim $\quad$ Tarihi: $\quad 12.10 .2014$ 